2006

\title{
Zarathustra’s Preposterous History
}

Joel Westerdale

Smith College, jpwester@smith.edu

Follow this and additional works at: https://scholarworks.smith.edu/ger_facpubs

Part of the German Language and Literature Commons

\section{Recommended Citation}

Westerdale, Joel, "Zarathustra's Preposterous History" (2006). German Studies: Faculty Publications, Smith College, Northampton, MA.

https://scholarworks.smith.edu/ger_facpubs/3 
Joel P. Westerdale

ZARATHUSTRA'S PREPOSTEROUS HISTORY

Abstract: What possible allure can a Persian prophet hold for a philhellenic philosopher? "Zarathustra's Preposterous History" discusses the conspicuous heritage of Nietzsche's figure, arguing that Nietzsche's turn to Zoroaster itself functions as an instance of affirmation, the difficult affirmation of even that which must be overcome. The self-overcoming that structures Also sprach Zarathustra comes to characterize the figure of Zarathustra itself, both within this book and in Nietzsche's later writings. But only through the preposterous imposition of this characterization can Nietzsche identify Zarathustra with Zoroaster and portray the moralist as the necessary precursor to the immoralist. Inverting chronology, Nietzsche not only affirms that which must be overcome, but also demonstrates how one can master the past by making of the "it was" of history a "thus I willed it."

Keywords: Zoroaster, Zarathustra, affirmation, history

Abstract: Warum befasst sich ein philhellenischer Philosoph mit einem persischen Propheten? Dieser Aufsatz diskutiert die augenfällige Erblast von Nietzsches Figur und argumentiert, dass Nietzsches Wendung zu Zoroaster selbst ein Beispiel der Bejahung abgibt, nämlich der schwierigen Bejahung dessen, was überwunden werden muss. Die Selbstüberwindung, die Also sprach Zarathustra strukturiert, charakterisiert ebenfalls die Zarathustra-Figur, sowohl in diesem Buch als auch in Nietzsches späteren Schriften. Aber nur durch die Rückübertragung dieser Charakterisierung kann Nietzsche Zarathustra mit Zoroaster identifizieren und den Moralisten als notwendigen Vorläufer des Immoralisten darstellen. Die Chronologie umkehrend, bejaht Nietzsche nicht nur das, was überwunden werden muss, sondern zeigt auch, wie man der Vergangenheit Herr werden kann, indem man aus dem „Es war“ der Geschichte ein „So wollte ich es“ macht.

Keywords: Zoroaster, Zarathustra, Bejahung, Geschichte

\section{Thus spoke who?}

Were it not for Nietzsche's Also sprach Zarathustra, few in the West would likely ever have heard the name Zarathustra. Though the innocent question, "Thus spoke who?" still prompts the facile equation of Zarathustra with the prophet whom the Greeks called Zoroaster, this standard response is no truly satisfying answer. Indeed it only exposes the true challenge that this figure's identity poses. For what promise does the arch-mage of the Persians hold for the classical philologist Nietzsche? Would the unabashed philhellenist actually have his readers identify his figure with this prophet from Persia of all places, even 
when Zoroaster's view of the world as an eternal battle of light and darkness stands at odds with one that seeks to get beyond good and evil? Rather than dissipating, questions proliferate at the association of Nietzsche's Zarathustra with history's Zoroaster, ${ }^{1}$ for the name alone, like so much of Nietzsche's writing, already presents a challenge, not only for the reader, but also to the reader; it is both a riddle and a provocation. As such, however, it is also a promise of interpretive possibilities. Zarathustra's identity, informed by his conspicuous heritage, is an essential and manifest aspect of the context in which Nietzsche situates the pronouncements of Also sprach Zarathustra, with the figuration of Zarathustra and the narrative in which he appears playing an integral role in determining the nature of Zarathustra's Lebren, or Anti-Lehren. ${ }^{2}$ But though scholars have come to acknowledge the distance between Nietzsche and his figure, and how the identification of Zarathustra with the historical Zoroaster reinforces Zarathustra's identity as one who overcomes himself, the performative quality of Nietzsche's choice of figures remains unremarked. And indeed, this is perhaps the most striking aspect of Nietzsche's turn to Zoroaster through the figure of Zarathustra: the choice itself, as a performative gesture.

Lamenting in Ecce homo that no one has inquired into the meaning of Zarathustra's name, Nietzsche verifies the identification of his character with the historical Zoroaster, while at the same time providing an account of the logic behind his turn to this particular figure. "Zarathustra hat zuerst im Kampf des Guten und Bösen das eigentliche Rad im Getriebe der Dinge gesehn," he writes, "Zarathustra schuf diesen verhängnissvollsten Irrthum, die Moral: folglich muss er auch der erste sein, der ihn erkennt" (EH, Warum ich ein Schicksal bin 3). The identification of Zarathustra with Zoroaster is unmistakable in this passage: as Zoroaster, he is the originator of the "sittliche] Weltordnung"; as Zarathustra, he recognizes the error of this world-view. Despite the apparent clarity of this simple explanation, one can sympathize with Curt Paul Janz' assessment that this account is "nicht restlos überzeugend." 3 The difficulty lies not in the identification of these two contrary figures, but in the adverb that implies a logical development from one to the other. Any illumination that this passage provides regarding the relationship between Zarathustra and Zoroaster hinges on the adverb "folglich." This term suggests that Zarathustra must be the first to overcome the moral world-view because he himself (as Zoroaster) was the first to assert it, and indeed, such a development corresponds with Zarathustra's

1 For the sake of clarity, in this article "Zarathustra" refers to the character in Nietzsche's writings, "Zoroaster" to the religious-historical figure.

2 See Werner Stegmaier, Anti-Lehren. Szene und Lehre in Nietzsches Also sprach Zarathustra, in: Volker Gerhardt (ed.), Friedrich Nietzsche. Also sprach Zarathustra, Berlin 2000, pp. $191-$ 224.

3 Curt Paul Janz, Friedrich Nietzsche. Biographie, 3 volumes, München 1993, vol. 2, p. 231. 
praise for self-overcoming and Nietzsche's characterization of Zarathustra as one who repeatedly overcomes himself. ${ }^{4}$ But the relation of logical consequence suggested by the term "folglich" is derived entirely from the retroactive imposition of this characterization upon Zoroaster. Such a maneuver presents not just a revision of history, but a vision of history that is literally preposterous, that is, a reinterpretation of history that inverts the chronology of consequence. Through this preposterous understanding of history, Nietzsche demonstrates the will's potential mastery over the past, making of the "Es war" of history a "So wollte ich es." Through his use of Zoroaster, Nietzsche the thinker becomes Nietzsche the doer, and the book becomes the deed of affirmation. ${ }^{5}$ The turn to Zoroaster as the basis for Zarathustra thus does not simply emphasize Zarathustra's capacity for self-overcoming. Presenting Zarathustra as Zoroaster's destiny enables a performance of affirmation - the affirmation of even that which must be overcome.

To investigate the initial allure of Zoroaster and demonstrate how the theme of temporality has long been associated with this figure, this study looks first to Nietzsche's textual sources. However, it is not exactly the kind of kritische Quellenforschung advocated by Andreas Urs Sommer, who poses the question, "Welchen Nutzen zeitigt Quellenforschung für das Verständnis eines philosophischen Textes?" The critical investigation of sources he advocates teaches us to recognize the text as something produced under specific conditions in response to specific questions, thus arousing a healthy distrust of the Nietzschean text. The current study, on the other hand, does not seek to induce additional wariness toward Nietzsche's claims for two basic reasons: firstly, the philosophical text under examination is already clad in the suspicious garb of narrative fiction; and secondly, although Nietzsche exploits historical sources, Also sprach Zarathustra does not engage in conventional historical discourse. Nietzsche's Zarathustra is a figure grounded less in the Zoroastrian Zend Avesta than in Nietzsche's own Western tradition. And this tradition becomes an extension of the figure he creates, as Nietzsche comes to metaleptically soften the distinction between history and invention, conflating his figure with the historical one. In doing so he invites the integration of his historical sources with his own figure, presenting his fictional prophet of affirmation as an actual historical instance of it. And indeed, as a moment of affirmation, Zarathustra can be seen to infiltrate history, as will become clear.

4 See Michael Skowron, Zarathustra-Lehren. Übermensch, Wille zur Macht, Ewige Wiederkunft, in: Nietzsche-Studien 33 (2004), pp. 68-89, pp. $69 \mathrm{f}$.

5 Cf. Volker Gerhardt, Die Erfindung eines Weisen. Zur Einleitung in Nietzsches Zarathustra, in: Gerhardt (ed.), Friedrich Nietzsche, pp. 1-15, pp. 3, 4.

6 Andreas Urs Sommer, Vom Nutzen und Nachteil kritischer Quellenforschung. Einige Überlegungen zum Fall Nietzsches, in: Nietzsche-Studien 29 (2000), pp. 302-316, p. 304. 


\section{Mage and Image}

Nietzsche's Zarathustra describes his name as both "lieb und schwer" (Za I, Von tausend und Einem Ziele), and scholarship addressing his relationship to the Persian prophet reflects this tension. The name Zarathustra leads some scholars to meticulously seek out Zoroastrian elements in Nietzsche's text, ${ }^{7}$ despite Nietzsche's admission that the dominant feature of Zoroaster's teachings, i. e., the division of the world into forces of good and evil, is directly at odds with Zarathustra's repeated demands that we move beyond this moralizing dichotomy. ${ }^{8}$ While such studies circumscribe the difficulty that Zarathustra's name poses for him, more common is the simple disregard for the assertion that he nevertheless holds his name dear. Karl Knortz' early monograph, for instance, suggests that Nietzsche's choice of character has little to do with Zoroaster at all: "Vom persischen Religionsstifter Zarathustra oder Zoroastar wissen wir im Allgemeinen so wenig, dass ihn Nietzsche ruhig als Stellvertreter wählen und ihm seine Weisheit in den Mund legen konnte." Stanley Rosen updates and refines this attitude by portraying Nietzsche's use of Zoroaster as an articulation of "a European literary convention: to criticize Europe from the assumed standpoint of an Oriental or outsider."10 Such an approach suggests that any number of exotic non-Europeans could just as well have served Nietzsche's purposes and thereby neutralizes any potential insight that Nietzsche's particular choice of character might provide. The net result is equivalent to those studies that, even when posing the question "Who is Nietzsche's Zarathustra?", effectively ignore the association with Zoroaster, opting instead to concentrate on precisely Nietrsche's Zarathustra. ${ }^{11}$

Rosen is right to note that Nietzsche's Zarathustra takes part in a European tradition, but this particular tradition, which reaches back over a thousand years, revolves around precisely the figure of Zoroaster, who is repeatedly portrayed as the kind of untimely outsider Nietzsche frequently privileges. During the Hel-

7 See William F. Scherer, Nietzsche and His Zarathustra. Vatic Poet - Tragic Vision, in: Roger L. Hadlich / J. D. Ellsworth (eds.), East Meets West. Honolulu 1988, pp. 275-282; Hushang Mehregan, Zarathustra im Awesta und bei Nietzsche - eine vergleichende Gegenüberstellung, in: Nietzsche-Studien 8 (1979), pp. 291-308; Fawzia Assaad-Mikhail, Zarathoustra interprète de Zarathoustra, in: Revue de métaphysique et de morale 74 (1969), pp. 161-200.

8 Jacques Duchesne-Guillemin describes Nietzsche's portrayal of Zoroaster as "almost the exact opposite of truth," (Jacques Duchesne-Guillemin, The Western Response to Zoroaster, Oxford 1956, p. 21).

9 Karl Knortz, Nietzsche's Zarathustra. Eine Einführung, Halle an der Saale 1906, p. 2.

10 Stanley Rosen, The Mask of Enlightenment. Nietzsche’s Zarathustra, Cambridge / New York 1995, pp. 7-8.

11 Martin Heidegger, Wer ist Nietzsches Zarathustra?, in: Vorträge und Aufsätze, Pfullingen 1954, pp. 101-126; cf. Günter Wohlfart, Wer ist Nietzsches Zarathustra? in: Nietzsche-Studien 26 (1997), pp. 319-330. 
lenistic period, forgeries appeared purporting to be the work of Zoroaster, a figure whom even the ancients considered ancient. Indeed, it seems that many texts seem more concerned with when Zoroaster lived than with what he actually said and wrote, deriving from his anteriority a kind of "exotic authority." 12 Pliny dates Zoroaster six-thousand years before the death of Plato in 317 BCE, ${ }^{13}$ a chronology echoed by Diogenes Laertius, who, citing Xanthus, situates him six-thousand years before Xerxes crossed the Hellespont in 480 BCE. ${ }^{14}$ Because of this anterior position, Zoroaster has been considered by many, both ancient and modern, to have exercised a strong influence on, or indeed to be the origin of, Greek philosophy. ${ }^{15}$ Multiple sources from antiquity, Plutarch among them, portray Zoroaster as the teacher of Pythagoras and thereby the bearer of a more ancient wisdom. ${ }^{16}$ The prevalence of pseudo-Zoroastrian forgeries, along with pseudepigrapha attributed to figures like Abraham and Hermes Trismegistus, create what Arnaldo Momigliano calls "the total impression of the dependence of Greek culture on barbarian wisdom." "17 Before developing his own character, Nietzsche himself refers to Zoroaster as Heraclitus" "Lehrer aus dem Orient" (PHG 1, KSA 1, p. 806) ${ }^{18}$ and mentions the influence of Eastern thought on the Greeks in his lectures on Pre-Platonic philosophy. ${ }^{19}$ Momigliano argues that there was "the implication that such barbarian wisdom was better absorbed at its sources (the pseudo-texts) than in its Greek derivatives: Zoroaster and Hermes Trismegistus must have been superior to Plato and Pythagoras if they were their masters." By attributing their texts to Zoroaster, the authors of these pseudepigrapha sought to exploit the authority derived from Zoroaster's anteriority.

12 Roger Beck, Thus Spake not Zarathuštra. Zoroastrian Pseudepigrapha of the Greco-Roman World, in: Mary Boyce / Frantz Grenet (eds.), A History of Zoroastrianism. Handbuch der Orientalistik, vol. 8, Leiden / Cologne 1991, pp.491-565, p. 509.

13 Pliny, Natural History, 30.3, trans. \& ed. W. H. S. Jones, London / Cambridge MA 1956, p. 279.

14 Diogenes Laertius, I, trans. R. D. Hicks, London / Cambridge MA 1972, p. 5; Diogenes Laertius is, of course, notoriously inaccurate, but accuracy is of limited interest to those investigating his influence on the image of Zoroaster.

15 Duchesne-Guillemin, The Western Response, p. 70; see also Arnaldo Momigliano, Alien Wisdom. The Limits of Hellenization, Cambridge 1978; Anton Hermann Chroust, Influence of Zoroastrian Teachings on Plato, Aristotle, and Philosophy, in: New Scholasticism 54 (1980), pp. 342-357; Ruhi Afnan, Zoroaster's Influence On Greek Thought, New York 1965.

16 Cf. Plutarch, De animae procreatione in Timaeo, 1012E; Hypolytus, In Refutation of all Heresies, 1.2.12; Clement of Alexandria, Stromata, 1.69; Apuleius, Florida, 15; Porphyry, Life of Pythagoras, 12; see Jenny Rose, The Image of Zoroaster. The Persian Mage Through European Eyes, New York 2000, p. $39 \mathrm{ff}$.

17 Momigliano, Alien Wisdom, pp. 146-147.

18 For a source of Nietzsche's, see Michael Skowron, Beiträge zur Quellenforschung. Nachweis aus Gladisch, August: Herakleitos und Zoroaster, in: Nietzsche-Studien 33 (2004), p. 373.

19 Held in the summer semesters of 1872 and 1876 and the winter semester of $1875 / 76$; KGW II.3, 428; II.4, 211; see Thomas Brobjer, Nietzsche's Reading About Eastern Philosophy, in: Journal of Nietzsche Studies 28 (2004), pp. 3-35, pp. 7, 11. 
Like the ancients, moderns would also seek to exploit this chronological priority, but not so much because of any implied authority. Rather Zoroaster's chronology situates him before the emergence Judeo-Christian discourse, providing a position from which to critique that discourse. Modern free spirits such as Giordano Bruno and Voltaire saw in Zoroaster a wisdom predating Christianity that could counteract the intellectually oppressive dogma of the church. ${ }^{20}$ Recognizing in the Persian prophet a representative of "natural religion," Voltaire would conscript Zoroaster in his campaign against l'infâme. In his Essai sur les Moeurs, ${ }^{21}$ he too privileges Zoroaster over such figures as Confucius and Pythagoras due to the fact that the Persian predates these others, and he sees in Zoroaster an alternative to Moses and a challenge to the church's monopoly on truth; the ancient mage opens up the possibility of truth untouched by JudeoChristian discourse. In the "Voltairian tradition," as Duchesne-Guillemin calls it, ${ }^{22}$ Zoroaster is valued not so much for any actual authority endowed by his chronological priority, but for the freedom from prejudicial contamination that this chronology represents. By co-opting the figure of Zoroaster as his own champion in the battle against Christianity, Nietzsche can be seen to fall into this "Voltairian tradition": he, too, adopts this figure of "alien wisdom" with little regard for the tenets of Zoroastrianism; he, too, seeks an alternative to JudeoChristian morality.

Zoroaster's position from which to criticize modern European culture seems to be derived less from geography than from chronology - he is a temporal Other. Thus seen, one can imagine the appeal that this figure might have for Nietzsche, whose writings teem with untimely - that is, unzeitgemäße - figures, such as the Philosopher of the Future, the Übermensch, and der tolle Mensch who "comes too soon."23 From his first Unzeitgemäße Betrachtungen in 1873 to the "Streifzüge eines Unzeitgemässen" of 1888, Nietzsche acknowledges and seeks to exploit the advantages of one out of step with contemporary culture. Such untimeliness, he asserts early on, allows one to be effective "gegen die Zeit und dadurch auf die Zeit und hoffentlich zu Gunsten einer kommenden Zeit" (UB II HL, Vorwort).

And indeed, Nietzsche introduces Zarathustra as just such a figure who is disconnected from his own contemporaries. In the course of Zarathustra's first

20 See Rose, The Image, p. 4.

21 Voltaire, Essai sur les Moeurs. In: Oeuvres complètes de Voltaire, vol. 22, Paris 1831, tome I, p. 467; see Rose, The Image, p. 99.

22 Duchesne-Guillemin, The Western Response, p.22; NB: Duchesne-Guillemin does not mention any advocates of this "tradition" other than Nietzsche, although he does claim that Shelley's Prometheus Unbound anticipates Nietzsche's “audacious Umwertung of Zoroaster” (p. 16).

23 See Steven V. Hicks / Alan Rosenberg, Nietzsche and Untimeliness. The 'Philosopher of the Future' as the Figure of Disruptive Wisdom, in: Journal of Nietzsche Studies 25 (Spring 2003), pp. $1-34$. 
public address in the opening section of Also sprach Zarathustra, it quickly becomes clear that the crowd assembled is not ready for what the hermit has to say - indeed, they mistake him for a barker. But rather than seeking to make himself understood, Zarathustra concedes his distance from his contemporaries: "Sie verstehen mich nicht," he says, "ich bin nicht der Mund für diese Ohren" (Za, Zarathustra's Vorrede 5). This first speech, or Rede, turns out to be indeed a Vor-Rede; it is literally a speech that comes too soon - it is an untimely speech. Nietzsche further invites the dissection of the term Vorrede into its constituent parts by giving the section in which the speech appears the same name as the speech itself - Zarathustra's Vorrede - and situating it directly before the section called "Die Reden Zarathustra's." Through the opposition of Vorrede / Rede, Nietzsche semantically reinforces the untimeliness of the character evident in Zarathustra's initial interaction with his contemporaries.

\section{Zoroaster's Story}

The initial resistance with which Zarathustra is greeted is not an invention of Nietzsche's. In his Culturgeschichte in ibrer natürlichen Entwicklung bis zur Gegenwart, Friedrich von Hellwald writes: "Zarathustra fand natürlich viele Gegner, namentlich in den Priestern der alten Religion." 24 One can imagine how this depiction would have appealed to Nietzsche. And indeed, though it is likely that various accounts influenced Nietzsche's understanding of Zoroaster, Hellwald's Culturgeschichte played a perceptible role in the development of Nietzsche's own character. When one considers what Nietzsche adopts and adapts from Hellwald, it becomes apparent that untimeliness constitutes but one potentially appealing attribute of Zoroaster; another is the story of his transformation.

During the period in which Nietzsche wrote Also sprach Zarathustra, that is, between 1883 and 1885, more than thirty books related to Zoroastrian texts were published in German,25 and many more were already in circulation. Nietzsche was certainly aware of Friedrich Spiegel's Eranische Alterthumskunde, ${ }^{26}$

24 Friedrich Anton Hellwald, Culturgeschichte in ihrer natürlichen Entwicklung bis zur Gegenwart. $2^{\text {nd }}$ Edition, Augsburg 1876, vol. 1, p. 169; see Paolo D’Iorio, Beiträge zur Quellenforschung, in: Nietzsche-Studien 22 (1993), pp. 395-97 (NB: D’Iorio utilizes the first edition, whereas as I only have access to the second; any discrepancies are noted below).

25 Rose, The Image, p. 178.

26 Friedrich Spiegel, Eranische Alterthumskunde. Leipzig 1871-1878; cf. Luca Crescenzi, Verzeichnis der von Nietzsche aus der Universitätsbibiothek in Basel entliehenen Bücher (1869-1879), in: Nietzsche-Studien 23 (1994), pp. 388-442, pp. 440 (\# 543) and 441 (\# 548); Assaad-Mikhail, Zarathoustra interprète, p. 163. 
and of Friedrich Creuzer's Symbolik und Mythologie der alten Völker, ${ }^{27}$ which he in fact came to own. ${ }^{28}$ But Hellwald's Culturgeschichte appears to have exercised the strongest influence on his understanding of Zoroaster and Zoroastrianism. Indeed, it is from Hellwald that Nietzsche likely adopted the name "Zarathustra." Though Duchesne-Guillemin claims that Nietzsche was the first European to prefer the Persian form of the name to the Greek "Zoroaster," 29 he overlooks Hellwald, who, while making note of the more common Greek spelling, uses "Zarathustra" consistently throughout his text.

Despite this apparent influence, however, one can overestimate the exactitude with which Nietzsche read and retained Hellwald's text. Thomas Brobjer, for instance, reads a letter from 23 April 1883 as evidence that Nietzsche had returned to Hellwald shortly after completing the first part of Also sprach Zarathustra. ${ }^{30}$ Here Nietzsche writes of a translation of the name "Zarathustra" that can indeed be found in Hellwald:

Heute lernte ich zufällig, was "Zarathustra” bedeutet: nämlich “Gold-Stern”. Dieser Zufall machte mich glücklich. Man könnte meinen, die ganze Conception meines Büchleins habe in dieser Etymologie ihre Wurzel: aber ich wußte bis heute nichts davon (Nietzsche to Heinrich Köselitz, 23 April 1883, KSB 6, no. 406).

Although Hellwald does mention this etymology in a footnote, he does so only to refute it. ${ }^{31}$ Nietzsche might have been less thrilled with the translation Hellwald actually prefers, namely "muthige Kameele besitzend" (and yet even less with Jenny Rose's translation: "having old camels"32). Most likely Nietzsche had Creuzer, and not Hellwald, in hand at the time, where the "Gold Star" etymology is perpetuated uncritically. ${ }^{33}$

Though Creuzer, who maintains the Greek "Zoroaster," mentions other possible renderings ("im Persischen Zeraduscht, und im Zend Zeretoschtro"), he does not mention "Zarathustra" at all. But Hellwald's influence on Nietzsche goes beyond the name "Zarathustra." His depiction of the Persians also sheds light on Zarathustra's cryptic portrayal of the values held by the people "aus dem [sein] Name kommt," namely, "Wahrheit reden und gut mit Bogen und Pfeil verkehren” (Za I, Von tausend und Einem Ziele). The first of these values, to speak

27 Georg Friedrich Creuzer, Symbolik und Mythologie der alten Völker, besonders der Griechen. 3. verbesserte Ausg., Leipzig / Darmstadt 1837-1842; cf. Crescenzi, Verzeichnis, p. 404 (\#202) and 418 (\#311).

28 Giuliano Campioni / Paolo D’Iorio / Maria Cristina Fornari / Francesco Fronterotta / Andrea Orsucci (Hg.), Nietzsches persönliche Bibliothek, Berlin / New York 2003, pp. 174-175.

29 Duchesne-Guillemin, Western Response, p. 21.

30 Brobjer, Nietzsche's Reading, p. 33.

31 Hellwald, Culturgeschichte, vol. 1, p. 169, fn 2.

32 Rose, The Image, p. 31, n 12.

33 Creuzer, Symbolik, vol. 1, p. 184. 
the truth, seems applicable to any number of cultures, but it is this value that Nietzsche would later again directly associate with Zarathustra in addressing the question of Zarathustra's name in Ecce homo: "Zarathustra ist wahrhaftiger als sonst ein Denker. Seine Lehre und sie allein hat die Wahrhaftigkeit als oberste Tugend" (EH, Warum ich ein Schicksal bin 3). Here Nietzsche need not be speaking of simply his own Zarathustra, but could indeed be referring to the Zoroaster and the Persians depicted by Hellwald, who also emphasizes the Zoroastrian commandment for truthfulness: for the Persians, "Wahrheit ist die Grundlage jeder Trefflichkeit, Unwahrheit dagegen eine der strafbarsten Sünden." 34 He goes on to say: "Wie schon erwähnt, ging es den Erâniern über Alles die Wahrheit zu sprechen und ihr Sagenschatz enthält Mythen, deren Moral in der Macht der aufrichtigen Sprache gipfelt; der gegenüber der Schlechte von innerlicher Ohnmacht befallen wird." The second virtue that Zarathustra attributes to the people who gave him his name, namely the virtue of handling bow and arrow well, seems somewhat more enigmatic, but again it bears the traces of Hellwald's portrayal of the Zoroastrians. Though not mentioning bow and arrow explicitly, he does emphasize the combative stance that Zoroaster's world-view promotes: "Zarathustra und sein Parsismus [zeigten] in der Welt einen grossen Kampfplatz, auf dem Jeder mitzukämpfen berufen ist - den Kampf um's Dasein!"35 Hellwald ascribes the great political role played by the Persians and the rise of their empire as a product of precisely this attitude.

But Hellwald's influence on Nietzsche can be most clearly recognized in Zarathustra's story. Pliny relates: "It is recorded of only one person, Zoroaster, that he laughed on the same day on which he was born, and also that his brain throbbed so violently as to dislodge a hand placed on his head." 36 Yet despite the richness of such a depiction and the importance of laughter for Zarathustra's philosophy, Nietzsche does not begin his story with Zarathustra's birth, but rather, one might say, with Zarathustra's rebirth. His is the story of the creator and legislator who retreats into the mountains to return with wisdom. As Hellwald relates, Zarathustra

war geboren in der Stadt Urmia am gleichnamigen See. Im dreissigsten Lebensjahre verliess er die Heimat, zog östlich in die Provinz Aria und verbrachte dort zehn Jahre in der Einsamkeit des Gebirges mit der Abfassung des Avesta beschäftigt. ${ }^{37}$

34 Hellwald, Culturgeschichte, vol. 1, p. 171.

35 Ibd.

36 Pliny, Natural History, 7.16.

37 Despite the title page's claim that the second edition of Hellwald is a "sehr vermehrte Auflage," this passage actually contains less information; the first edition situates Urmi and the lake of the same name "zwischen Kaspi- und Van-See" (Friedrich Anton von Hellwald, Culturgeschichte in ihrer natürlichen Entwicklung bis zur Gegenwart, Augsburg 1875, p.128). 
This account makes it into Nietzsche's notebooks under the title, "Mittag und Ewigkeit. Fingerzeige zu einem neuen Leben," with little modification:

Zarathustra, geboren am See Urmi, verliess im dreissigsten Jahre seine Heimat, gieng in die Provinz Aria und verfasste in den zehn Jahren seiner Einsamkeit im Gebirge den Zend-Avesta (Nachlaß 1881, KSA 9, 11[195]).

The similarity leaves little doubt as to the provenance of this passage, although Nietzsche omits some geographical details. And indeed, in each consecutive formulation of this passage, Nietzsche would continue to excise such particulars. When in the Fröbliche Wissenschaft he introduces Zarathustra into his published writings, he writes:

Incipit tragoedia. - Als Zarathustra dreissig Jahr alt war, verliess er seine Heimath und den See Urmi und gieng in das Gebirge. Hier genoss er seines Geistes und seiner Einsamkeit und wurde dessen zehn Jahre nicht müde (FW 342).

Though the lake survives, the name of province and the text composed no longer appear. And in the final version of this passage, which opens Also sprach Zarathustra, all particulars, textual and geographical, have been eradicated. Only Zarathustra and his story remain:

Als Zarathustra dreissig Jahr alt war, verliess er seine Heimat und den See seiner Heimat und gieng in das Gebirge. Hier genoss er seines Geistes und seiner Einsamkeit und wurde dessen zehn Jahre nicht müde (Za, Zarathustra's Vorrede 1).

The course of this gradual development from Hellwald's Culturgeschichte to Also sprach Zarathustra reveals the essential elements of this passage. What remains are not the particulars of Zoroaster's biography, not where he came from, where he went, or what he wrote, but rather the narrative itself. Nietzsche is not concerned with Zoroaster's writings and how he occupied himself over those ten years. The lure of Zoroaster, it appears, is not Zoroastrianism or the Zend-Avesta, but his story as an isolated creator and legislator in the process of becoming. By expunging biographical detail, Nietzsche foregrounds the story itself, emphasizing transformation as the essence of Zarathustra's narrative.

\section{Zarathustra's Narrative}

Almost immediately after recording Hellwald's introduction of Zoroaster, Nietzsche writes in the same notebook: "Die unablässige Verwandlung - du musst in einem kurzen Zeitraume durch viele Individuen hindurch. Das Mittel ist der unablässige Kampf” (Nachlaß 1881, KSA 9, 11[197]). And indeed, it would seem that by identifying his Zarathustra with the historical Zoroaster, 
Nietzsche is portraying such a continued transformation of the individual. When considered in light of the actual opposition between history's Zoroaster and Nietzsche's Zarathustra, the identification of these two figures emphasizes the possibility of Zarathustra's development, a development that takes place not only in the trajectory from Zoroaster to Zarathustra, but within the narrative course of Also sprach Zarathustra.

As mentioned above, Nietzsche writes, "Zarathustra hat zuerst im Kampf des Guten und Bösen das eigentliche Rad im Getriebe der Dinge gesehn, [...] Zarathustra schuf diesen verhängnissvollsten Irrthum, die Moral: folglich muss er auch der erste sein, der ihn erkennt.” (EH, Warum ich ein Schicksal bin 3) The first part of this statement must refer to the historical Zoroaster, who saw the world as the eternal battle of light and darkness; the second half, however, can only refer to Nietzsche's Zarathustra, for the historical Zoroaster issues no such recantation. But although Zarathustra's message can be seen to conflict directly with that of the historical Zoroaster, Nietzsche does not seek to replace one history with another. Rather he describes his fictional figure as an extension of the historical one; he writes that in the matter of morality, Zarathustra "länger und mehr Erfahrung hat als sonst ein Denker," implying an historical continuity that links the ancient mage to the figure in Nietzsche's narrative. Nietzsche's Zarathustra is thus not distinct from the historical figure of Zoroaster, but a continuation of him that has developed beyond the Zoroastrian.

This relation of contrast and continuity reinforces Zarathustra's development within the narrative course of $A$ lso sprach Zarathustra that many readers continue to overlook. In their quest to discern the book's argumentative development, scholars like Arthur Danto downplay the potential influence of narrative development on interpretation, asserting that because ordered argumentation is lacking, Also sprach Zarathustra "may be entered at any point." 38 It is unlikely that Danto would have said the same thing of, say, Wilhelm Meister, but only because such books are expressly narrative, and in his eyes, we must assume, Also sprach Zarathustra is not. Danto applies the same reading strategy to Also sprach Zarathustra that he develops for Nietzsche's aphorisms, yet Nietzsche himself, in a letter to Franz Overbeck, demands a different approach: "Es ist eine Dichtung," he writes of his current project, "und keine Aphorismen-Sammlung" (10 February 1883, KSB 6, no. 373). As such, forced entry into the text "at any point" could be seen as a encroachment on at least the author's understanding of the work's generic integrity.

Heidegger adopts a comparable approach when he describes Nietzsche's Zarathustra as an advocate: ${ }^{39}$ by determining that which he advocates, we ap-

38 Arthur C. Danto, Nietzsche as Philosopher. An Original Study, New York 1965, p. 20.

39 Heidegger, Wer ist Nietzsches Zarathustra?, pp. $101 \mathrm{ff}$. 
proach the answer to the question, Who is Nietzsche's Zarathustra? And who is he? He is the teacher of the Übermensch, the will to power, of the eternal recurrence of the same. It is not, however, this aspect of Zarathustra's character that Nietzsche emphasizes in Ecce homo, but rather the capacity for overcoming, an overcoming that the conflation of the historical Zoroaster and Nietzsche's Zarathustra enables us to understand as a self-overcoming: "Zarathustra schuf diesen verhängnissvollsten Irrthum, die Moral: folglich muss er auch der erste sein, der ihn erkennt. [...] Die Selbstüberwindung der Moral aus Wahrhaftigkeit, die Selbstüberwindung des Moralisten in seinen Gegensatz - in mich - das bedeutet in meinem Munde der Name Zarathustra” (EH, Warum ich ein Schicksal bin 3). The image of Zarathustra derived from this portrayal is not so much that of an advocate of a particular doctrine, but of one who is able to overcome even that which he has hitherto advocated. With this image in mind, we can see how it is borne out by the narrative of Also sprach Zarathustra, both on the small scale of the prologue and on the larger scale of the narrative as a whole.

After his failure in the marketplace, Zarathustra realizes that he can no better force his message upon the crowd than the blind hermit can force the dead acrobat to eat. He reevaluates his communicative approach, correcting his course. ${ }^{40}$ Turning away from the crowd, Zarathustra decides to seek companions, signalling a new beginning. And indeed, "Zarathustra's Vorrede" can be seen as a story of new beginnings. The very first section of Also sprach Zarathustra concludes not with the refrain that gives the book its name, but rather with the phrase, "Also begann Zarathustra's Untergang." This line is repeated twice in the "Vorrede," both times at privileged moments: at the close of the first section (Za, Zarathustra's Vorrede 1) and at the end of the entire prologue (Za, Zarathustra's Vorrede 10). While scholarly attention has tended to concentrate on this "Untergang," it is the simple "begann" that is of interest here. The repetition of this phrase raises a problem absent in the refrain, "Also sprach Zarathustra." Twice Zarathustra begins to go under: upon leaving his mountain retreat to share his wisdom with the crowd, and again upon retreating from the crowd after realizing the futility of this strategy. Through the repetition of beginning in the prologue, Zarathustra is introduced not only as an iconoclast, but as one who can self-critically re-assess his own approach and is capable of starting anew.

Such self-critical reevaluation is not limited to issues of method, but informs the content of Zarathustra's teachings. The history Nietzsche lays out in Ecce homo has Zarathustra initially teaching that the world is divided into forces of good and evil, yet he overcomes this doctrine. A similar development occurs

\footnotetext{
40 Kathleen Higgins reads a shift in Zarathustra's speech from the abstract in part 3 of "Zarathustra's Prologue" to the metaphoric and parabolic (in parts 4 and 5) as indications of Zarathustra's communicative corrections (Kathleen Higgins, Nietzsche’s Zarathustra. Philadelphia 1987, p. 84).
} 
within Also sprach Zarathustra, which begins with Zarathustra teaching the concept of the Übermensch, only to modify this concept with his subsequent affirmation of eternal recurrence. Robert Pippin has argued that Zarathustra's teachings undergo a radical development in the course of the narrative due to the tension that emerges between the Übermensch-ideal and eternal recurrence. ${ }^{41}$ The eternal recurrence of the same does not simply imply that all things recur eternally, in every aspect over and over again, but that one must be able to affirm this image of the world, that one might honestly say, "War das das Leben? Wohlan! Noch Ein Mal!” (Za III, Vom Gesicht und Räthsel 1). The ideal of the Übermensch laid out at the beginning of the narrative, however, stands in the way of such affirmation by fostering resentment against those whom the Übermensch must overcome.

Nietzsche portrays this resentment toward the end of the book's third part, as Zarathustra describes how a creature had crawled into his throat and choked him; this creature, he says, is "[d]er grosse Überdruss am Menschen" which is fed by his frustration "dass sein Bösestes so gar klein ist! Ach dass sein Bestes so gar klein ist!” (Za III, Der Genesende 2, KSA 4, p. 274). This disgust with contemporary man, which fuels the Übermensch-ideal, becomes a liability in light of eternal recurrence - Zarathustra must be able to affirm that "der Mensch, dess [er] müde [ist], der kleine Mensch" also recurs eternally. By biting off and spitting out the head of the creature that has crawled into his throat, Zarathustra describes the gesture of overcoming his resentment against the small man, and in doing so moves beyond the motivation hitherto driving the Übermensch-ideal.

Volker Gerhardt writes, "Zarathustras Weg illustriert den Zuwachs an Einsichten, die der Autor längst hat,"42 and this becomes evident when one contrasts the gradual manner in which Zarathustra comes to acknowledge the eternal recurrence and Nietzsche's account in Ecce homo of the suddenness with which the idea occurred to him (EH, Zarathustra 1). That Zarathustra gradually develops toward the affirmation of the eternal recurrence and away from the Übermensch-ideal is already suggested by the manner in which both the idea of eternal recurrence and the figure of Zarathustra enter into Nietzsche's writings, not in Also sprach Zarathustra, but in the Fröbliche Wissenschaft. Nietzsche introduces the eternal recurrence and Zarathustra in the final two aphorisms of the first edition of the Fröbliche Wissenschaft, that is, in the two passages that directly precede Also sprach Zarathustra in Nietzsche's publication history. And though he does not include them in the same passage, the proximity and privileged posi-

\footnotetext{
41 Robert Pippin, Irony and Affirmation in Nietzsche's Thus Spoke Zarathustra, in: Nietzsche's New Seas. Chicago / London 1988, pp. 45-71.

42 Gerhardt, Die Erfindung, p. 5.
} 
tioning of these two texts implies a strong association. Both passages anticipate Nietzsche's coming work.

Although Nietzsche does not mention the term "ewige Wiederkunft" or "ewige Wiederkehr" explicitly in the Fröbliche Wissenschaft, he introduces the concept in the penultimate section of the fourth book as a hypothetical situation: "Wie, wenn dir eines Tages oder Nachts, ein Dämon in deine einsamste Einsamkeit nachschliche und dir sagte: "Dieses Leben, wie du es jetzt lebst und gelebt hast, wirst du noch einmal und noch unzählige Male leben müssen“" (FW 341). In the passage directly following this one, Nietzsche introduces Zarathustra to his reading audience (FW 342) and with that closes the first edition of the Fröhliche Wissenschaft. Despite the strong association implied by the immediate proximity of these passages, both to each other, and, in terms of publication history, to Also sprach Zarathustra, Nietzsche waits until the end of the Second Part of Also sprach Zarathustra to introduce the eternal recurrence into the book, and then only as a sense of foreboding. Although conceptually present, one might say, from the time of the Fröbliche Wissenschaft, the "Grundconception des Werks, der Ewige-Wiederkunfts-Gedanke, diese höchste Formel der Bejahung” (EH, Also sprach Zarathustra 1), becomes something that Zarathustra must work toward. Those who would contend that one can simply jump into Zarathustra at any point suppress the possibility that Zarathustra, as a figure, is not presented as a fully-formed individual, but as one who undergoes a process of development toward this "fundamental" concept.

Nietzsche's turn to narrative in Also sprach Zarathustra and his turn to the figure of Zarathustra can thus be seen as fruit of the same tree. The identification and opposition of Zarathustra and Zoroaster already insinuates a narrative by placing the two along a single developmental continuum. The narrative of self-overcoming is then reiterated in parallel fashion over the narrative course of Also sprach Zarathustra. This continuous development, one might argue, has a destabilizing effect on Zarathustra's proclamations, for by characterizing Zarathustra not only as one with the intestinal fortitude to re-evaluate his own doctrines, but as one who actually undergoes such transformation, Nietzsche discourages any attempt by the reader to distill Zarathustra's message into a static, universal dogma. Thus Zarathustra's often-cited admonition to his followers to go away and resist Zarathustra takes on additional meaning - he beseeches them to resist the temptation to dogmatically assert the universal validity of his teachings, not simply because to do so challenges Nietzsche's perspectivism, but because it also implies a stability to Zarathustra's beliefs belied by the narrative of his development. To reduce his speeches to concrete Lehren would preclude the possibility of further reevaluation and thereby deny the possibility of the self-overcoming by which Nietzsche characterizes his figure. But the identification of Zarathustra with Zoroaster presents more than a denial of dogmatic stability; it presents a moment of affirmation. 


\section{Zarathustra's Performance}

According to Josef Simon, Zarathustra is doomed to fail as a teacher because he asserts that there is no truth to be taught, yet the use of the narrative form in Also sprach Zarathustra enables Nietzsche himself to demonstrate the plight of the teacher without falling victim to the teacher's dilemma. ${ }^{43}$ One might argue that the narrative form not only allows Nietzsche to avoid the dilemma of a teacher for whom there is no truth, but it also permits Zarathustra to remain a teacher by continuing to teach by example. As Michael Skowron maintains: "Zarathustra ist in einem eminenten Sinn auch das, was er lehrt, ein Lehrer als Beispiel." "44 Skowron argues that in the course of Zarathustra's development he moves not only from Zoroaster to Zarathustra, but from the doctrine of the Übermensch through the will to power to the eternal recurrence. As the narrative of Also sprach Zarathustra progresses, so does Zarathustra, and this progress itself is an manifestation of Zarathustra's Lehren.

The shadow of Zoroaster in Zarathustra's past helps to initiate this narrative of self-overcoming that begins in history and evolves into fiction. But Nietzsche does not acknowledge this distinction; he does not just base his figure on the historical Zoroaster - he identifies the two. He does not subordinate his invention to historical accounts, but rather, he allows Zarathustra to metaleptically infiltrate history, rupturing the boundary separating the diegetical confines of Zarathustra's narrative from an extradiegetical reality. Zarathustra is presented as more than a fictional example of self-overcoming; he appears as actual instance of it, and as such, he becomes an actual instance of affirmation - the affirmation of even that which must be overcome. In the figure of Zarathustra, Nietzsche revises the past without prompting resentment against that which requires revision. He transforms the "Es war" of history into a "So wollte ich es" by presenting Zoroaster as the necessary progenitor of Zarathustra. In this way, the figure of Zarathustra, as based on the figure of Zoroaster, is more than simply a teacher, and more than simply an example - he constitutes as a figure a performative instance of the affirmation that he advocates.

The performative quality of Zarathustra has not gone entirely unremarked. In Claus Zittel's analysis, Zarathustra's statements at times self-reflexively do what they say. For instance, he reads the following passage from the chapter, "Von der Erlösung," as a poetological metacommentary on Nietzsche's poetic program:

\footnotetext{
${ }^{43}$ Josef Simon, Ein Text wie Nietzsches Zarathustra, in: Gerhardt (ed.), Friedrich Nietzsche, pp. 225-256, p. 234.

44 Skowron, Zarathustra-Lehren, p. 69.
} 
Und das ist all mein Dichten und Trachten, dass ich in Eins dichte und zusammentrage, was Bruchstück ist und Räthsel und grauser Zufall [...]. Die Vergangenen zu erlösen und alles "Es war" umzuschaffen in ein "So wollte ich es!" - das hiesse mir erst Erlösung. (Za II, Von der Erlösung, KSA 4, p. 179).

In Zittel's account, this passage not only describes Zarathustra's method; it provides an example of it by appropriating Bruchstücke in the form of quotations from external sources in a productive manner. ${ }^{45}$ The phrase "Dichten und Trachten," as a quotation from Genesis 6, provides the Bruchstück, and recognizing this reference leads the reader to compare Zarathustra's practice to the evil "Dichten und Trachten" in the hearts of men that leads God to expunge them from the face of the earth. Employing such a Bruchstück, Zarathustra's statement does what it describes, producing what we can call a performative text.

And yet by portaying this passage as a kind of poetological metacommentary on Nietzsche's part, Zittel comes dangerously close to perpetuating the identification of Zarathustra and Nietzsche that he himself justifiably denounces. ${ }^{46}$ These remarks by Zarathustra, he contends, not only contain the views of the protagonist, "sondern anhand ihrer Form thematisiert der Autor Nietzsche auf einer Metaebene zugleich seine eigenen artistischen Verfahren und ihren Anteil bei der Sinnkonstitution" ${ }^{47}$ While the passage is undeniably self-reflexive, that self-reflexivity permits diverse readings. First, that which Zittel describes reflects Zarathustra more strongly than than it does Nietzsche. It is Zarathustra who alludes to the Bible, and thus Zittel's reading, while providing insight into Zarathustra's method (and the obligatory "metalevels"), only reflects Nietzsche's approach if we identify the two. Nevertheless, we might see this passage as a reflection on Nietzsche's method if we read the Bruchstück to refer not simply to Zarathustra's biblical allusion, but to the figure of Zarathustra himself. Zarathustra himself, as we have seen, is already a kind of fragment and quotation from elsewhere, brought together not by Zarathustra, but rather in Zarathustra. This second level of self-reflexivity enables a second level of performativity. In Zittel's account, Zarathustra's statement does what it describes by employing the Bruchstück of biblical allusion, thus providing a degree of performativity on the level of the statement. Such performativity, however, remains to some degree offset by an economy of quotation marks, ${ }^{48}$ with Zarathustra's text performing that which Zarathustra is saying. But the Nietzschean figure of Zarathustra, when seen as contituted by such Bruckstücke, renders the text Also sprach Zarathustra

45 Claus Zittel, Das ästhetische Kalkül von Friedrich Nietzsches Also sprach Zarathustra, Würzburg 2000 , p. 31.

46 Ibd., p. 17.

47 Ibd., p. 160.

48 Cf. Peter J. Burgard, Introduction: Figures of Excess, in: Peter J. Burgard (ed.), Nietzsche and the Feminine, Charlottesville VA 1994, pp. 1-32, p. 4 ff. 
itself, and not simply the statements contained therein, a performance of the above statement. But the performativity to be discerned in the figure of Zarathustra does more than simply reinforce a poetological strategy of fragmental allusion - it provides an instance of affirmation.

Zittel's choice of passage is intriguing not only for the self-reflexivity he astutely recognizes, but also for the promise of redemption associated with this self-reflexivity. This redemption comes not from on high, but though a capacity for affirmation that extends even to that over which one cannot directly exert one's will: the past. 'Die Vergangenen zu erlösen und alles 'Es war' umzuschaffen in ein 'So wollte ich es!' - das hiesse mir erst Erlösung." The will is threatened by the restrictions of linear time, by this "Es war" of history - it is "des Willens Zähneknirschen und einsamste Trübsal. Ohnmächtig gegen Das, was gethan ist" (Za II, Von der Erlösung, KSA 4, pp. 179-180). And yet through the affirmation of the past, through the ability to assert "So wollte ich es," one redeems oneself from the desire that the past be otherwise. The will no longer experiences the past as a limitation on it power, but rather as an extension of itself.

Such a strategy can, for example, be seen at work in one of Nietzsche's most widely recognized statements: "Aus der Kriegsschule des Lebens. - Was mich nicht umbringt, macht mich stärker" (GD, Sprüche und Pfeile 8). This is among Nietzsche's most often-quoted statements. ${ }^{49}$ But the source of its popularity lies most likely not so much in the actual veracity of the statement as in the attitude it expresses. This attitude fortifies one's ability to cope with adversity, both present and past, and enables one to draw strength from all eventualities. Any depletion of power short of complete destruction is simply not acknowledged as a possibility. With an eye to the past (as the title of the passage suggests the author has), such an approach arms one against the inexorableness of what has gone before, not by actually altering the past (which not even a cosmological understanding of eternal recurrence would allow), but by reevaluating one's attitude toward the past in all its inexorability.

Another attempt to make of the "Es war" of history a "So wollte ich es" can be discerned in Nietzsche's notorious self-stylization. For those familiar with Nietzsche's works, the author's absence from Also sprach Zarathustra is initially conspicuous, for the one Nietzschean character with whom people are most familiar is indeed Nietzsche himself. Throughout his career, Nietzsche would inscribe himself ever more into his works, even returning later in his career to his earlier works to personalize them with new prefaces..$^{50}$ This process culminates

49 Finding its way into the mouth of Doogie Howser, no less; see Bernd Magnus / Kathleen M. Higgins, Introduction to The Cambridge Companion to Nietzsche, in: Bernd Magnus / Kathleen M. Higgins (eds.), The Cambridge Companion to Nietzsche, Cambridge 1996, pp. 1-17, p. 2.

50 Nietzsche wrote new prefaces to GT and both MA I and II in 1886; to M and FW in 1887. 
in the tellingly titled Ecce homo. The Nietzsche that emerges, rather than gnashing his teeth at his own famously miserable physical condition, praises the insight with which his ill health provides him. ${ }^{51}$ Following Zarathustra's prescription for redemption by overcoming resentment of the past, for instance, he reinterprets his notorious break with Wagner with the claim: "über unsern Himmel ist nie eine Wolke hinwegegangen” (EH, Warum ich so klug bin 5). But the greater moment of affirmation is the creation of the figure of Zarathustra itself.

For some, the figure of Zarathustra provides a portrayal of what a healthy response to the eternal recurrence might look like. Heidegger writes that Nietzsche's thoughts are so untimely that he must first create poetically the thinker (Zarathustra) who can think the most abysmal thought of the eternal recurrence. ${ }^{52}$ But the real obstacle is not simply to think the thought, but to laugh the laugh; to believe in the eternal recurrence and not be crushed by it. In the passage from the Fröbliche Wissenschaft in which Nietzsche introduces the eternal recurrence, the concept is formulated as a hypothetical: "What, if some day or night a demon were to steal after you in your loneliest loneliness [...]." Regardless of whether Nietzsche may have proposed a cosmological understanding of the eternal recurrence, for Zarathustra, the situation is not hypothetical; he actually seems to believe in its veracity. He may not say "never have I heard anything more divine," but neither does he despair entirely. The book ends with "Das Zeichen," the laughing lion and the flock of doves that signal yet another going down and going under reminiscent of the work's prologue.

The moment of affirmation that Zarathustra represents, however, does not lie in the narrative of Also sprach Zarathustra. Zarathustra does not actually provide an example of unequivocal affirmation within the bounds of the narrative, but as a figure he does present a performance of affirmation not confined to the world of invention. Through his depiction of Zarathustra, Nietzsche demonstrates the malleability of history by asserting the porous boundary separating history and fiction and allowing free passage between the register of truth and the domain of invention. This maneuver does more than foreground the historical aspects of the literary and the literary aspects of the historical - it sets the stage for a preposterous transfiguration of history. Zarathustra does not simply preach affirmation, nor does he simply teach by example within the bounds of a closed narrative - he slips into the realm of history where his performance of affirmation can take place.

From the outset, Also sprach Zarathustra assails the distinction between the diegetical and the extradiegetical. The ill-received speech with which Zarathustra begins his mission, referred to in the text as "Zarathustra's Vorrede" (Za, Zara-

51 See, e. g., EH, Warum ich so weise bin 1, and EH, MA 4.

52 Martin Heidegger, Nietzsche, trans. David Krell, New York 1982, vol. 2, p. 30. 
thustra's Vorrede 5), appears in the section that opens the book, likewise called “Zarathustra's Vorrede." Most of Nietzsche's published works begin with a prologue (Vorrede), most of these composed years after the works' initial publications. ${ }^{53}$ In general, these opening passages discuss with some degree of distance the works they introduce. But not so with "Zarathustra's Vorrede." This opening section does not provide an extradiegetical discussion of the book, but rather it launches the narrative. The title of the section may be seen simply to describe that which it depicts, namely a speech called "Zarathustra's Vorrede," but at the same time, the position of this section at the beginning of the book naturally suggests that it also serves the function of a Vorrede - "und schon beginnt das angesprochene poetologische Doppelspiel von Figur und Werk," as Peter Villwock puts it, "es ist die Vorrede zum Buch Zarathustra, und es ist die erste Rede der Figur Zarathustra, vor dem darauf folgenden Haupttext, der mit Die Reden Zarathustra's überschrieben ist." 54 If we consider the term "Vorrede" to describe the section's function, then the "Zarathustra" that precedes it refers not to the character, but rather it operates as an abbreviated form of the book's title. The practice of reducing the title thus is not uncommon today, ${ }^{55}$ though we feel compelled to take advantage of definitive scholarly apparatus which Nietzsche, whether intentionally or not, does not apply with any sort of regularity. The impression that the term "Vorrede" in "Zarathustra's Vorrede" refers to function rather than content is reinforced by the meager amount of space actually devoted to the speech, which makes up only three of the prologue's ten parts.

The opening two words of Also sprach Zarathustra straddle both diagetic and extradiegetic realities. In doing so, they prefigure the position that Zarathustra himself comes to occupy. Nietzsche situates this figure with one foot in the narrative and one foot beyond, as a character both invented and autonomous who enters the ontological realm of the historical Zoroaster and the author Nietzsche. Without the benefit of a definitive scholarly apparatus, such as italics or Sperrschrift, it is often difficult to determine whether Nietzsche intends the word "Zarathustra" to refer to the book itself or to the figure from the book. And at times it seems that Nietzsche intentionally exploits this ambiguity, for instance when he writes in Ecce homo:

53 Already early in his career Nietzsche demonstrates a certain degree of playfulness with regard to front matter, opening the first edition of MA with the text "An Stelle einer Vorrede" (1878) which he would later replace with an actual prologue (1886; see KSA 2, p. 11); consider also the "Fünf Vorreden zu fünf ungeschriebenen Büchern" (KSA 1, pp. 753-792).

54 Peter Villwock, Zarathustra. Anfang und Ende einer Werk-Gestalt Nietzsches, in: Peter Villwock (ed.), Nietzsches "Also sprach Zarathustra”, Basel 2001, pp. 1-34.

55 See, e. g., Rosen, The Mask of Enlightenment, and Gerhardt, Die Erfindung. 
Dass ein Goethe, ein Shakespeare nicht einen Augenblick in dieser ungeheuren Leidenschaft und Höhe zu athmen wissen würde, dass Dante, gegen Zarathustra gehalten, bloss ein Gläubiger ist und nicht Einer, der die Wahrheit erst schafft, ein weltregierender Geist, ein Schicksal -, dass die Dichter des Veda Priester sind und nicht einmal würdig, die Schuhsohlen eines Zarathustra zu lösen, das ist Alles das Wenigste und giebt keinen Begriff von der Distanz, von der azurnen Einsamkeit, in der dies Werk lebt. (EH, Also sprach Zarathustra 6)

Here Nietzsche confounds the distinction between Zarathustra the character and Zarathustra the book. Though he writes of the solitude of the Werk, it is doubtful that this work has shoes. In this metaleptic moment, ${ }^{56}$ Nietzsche likens his Zarathustra not to Faust or Hamlet, but to Goethe and to Shakespeare. Doing so allows the figure to transgress the bounds of the narrative and to contaminate the domain of the author. Zarathustra moves from the realm of fiction back to that of history whence he came.

This metaleptic shift, facilitated even as it is complicated by Zarathustra's prior position in Western history as Zoroaster, becomes all the more disconcerting when Nietzsche places himself along a trajectory established by the development from history's Zoroaster to his own Zarathustra. The development Nietzsche traces in Ecce homo does not end with Zarathustra:

Die Selbstüberwindung der Moral aus Wahrhaftigkeit, die Selbstüberwindung des Moralisten in seinen Gegensatz - in mich - das bedeutet in meinem Munde der Name Zarathustra. (EH, Warum ich ein Schicksal bin 3)

The continuum stretching back from Zarathustra to Zoroaster continues forward to Nietzsche himself. The implied identification with Zarathustra is reinforced by the fact that Nietzsche addresses the question of Zarathustra's name not in the section of Ecce homo specifically dedicated to Also sprach Zarathustra, but rather in the chapter which purports to answer, "Warum ich ein Schicksal bin" [emphasis JW]. As part of this continuum of development, the figure Zarathustra can be seen to occupy a kind of ontological limbo, as a literary figure linking two historical ones in a relationship of identification and opposition.

And yet the historical figures of Zoroaster and Nietzsche do not actually occupy a position fundamentally different from that of Zarathustra in Nietzsche's writings. Nietzsche himself recognizes the ontologically insignificant position of the author with regard to the work. The stylized figure of Nietzsche is no less a figure than Zarathustra, as indeed Nietzsche himself suggests in a passage from Jenseits von Gut und Böse that anticipates the Death of the Author:

das „Werk“, das des Künstlers, des Philosophen, erfindet erst Den, welcher es geschaffen hat, geschaffen haben soll; die ,grossen Männer“, wie sie verehrt werden, sind kleine schlechte Dichtungen hinterdrein (JGB 269)

56 Metaleptic in a narratological rather than rhetorical sense. 
Alexander Nehamas argues that Nietzsche, rather than describing his ideal character, exemplifies it as himself in his writings. ${ }^{57}$ So that he might make claims in a manner consistent with his own perspectivism, Nietzsche "create[s] an artwork out of himself, a literary character who is a philosopher," 58 with all the idiosyncrasies one expects; this allows him to overcome the apparent obstacle of making assertions without becoming dogmatic.

Once the border separating history and literature is opened, it allows for traffic in both directions. What enables Nietzsche to create an artwork of himself also enables him to render his literary creation as history. And in doing so he undertakes to revise history, not by directly altering it, but by demonstrating how it has led to something worthy of his approbation. That the will cannot will backwards, says Zarathustra, "das ist des Willens einsamste Trübsal” (Za II, Von der Erlösung, KSA 4, p. 180), for the will appears to have reached an insurmountable impediment in linear time. Yet he goes on to suggest a way to circumvent this obstacle: “Alles 'Es war' ist ein Bruchstück, ein Räthsel, ein grauser Zufall bis der schaffende Wille dazu sagt: 'aber so wollte ich es!”' (ibd., p. 181). And this is precisely what Nietzsche does by taking the historical figure responsible for what he considers the "verhängnissvollsten Irrthum" in human history, "die Moral," and turning him into the figurehead of his philosophy.

The historical Zoroaster provides Nietzsche with a figure of untimeliness and with the narrative of a lone creative legislator who undergoes a fundamental transformation, and his identification with and opposition to Nietzsche's Zarathustra foregrounds the figure's potential for self-overcoming. But precisely the element of opposition necessary for this drama of self-overcoming, the demand that Zoroaster's division of the world into good and evil be overcome, harbors the potential for resentment against this Zoroaster. How can one affirm that which one admits must be overcome? How can Zarathustra affirm the moral world order initiated by Zoroaster while at the same time advocating the abolishment of this order? Much as Zarathustra's resentment against the small man who must be overcome must itself be overcome, so too must the resentment be overcome against him who first devised the morality Zarathustra seeks to overcome. Zoroaster and his mendacious invention have slithered into Nietzsche's throat and bitten fast, and he must himself bite down and spit it out.

"So ihr aber einen Feind habt," proclaims Zarathustra after being bitten on the neck by an adder, "so vergeltet ihm nicht Böses mit Gutem: denn das würde beschämen. Sondern beweist, dass er euch etwas Gutes angethan hat” (Za I, Vom Biss der Natter). And that is what Nietzsche does with the historical figure he associates with the emergence of morality. Positioning Zoroaster on a con-

57 See Alexander Nehamas, Nietzsche. Life as Literature, Cambridge MA 1985, p. 232.

58 Ibd., p. 8. 
tinuum leading toward something that Nietzsche genuinely celebrates, namely Zarathustra, facilitates the potential recuperation of the Persian mage. Zoroaster may have created this moral world order, but in Nietzsche's portrayal, he comes to recognize the error of his ways, overcomes himself, and maneuvers himself beyond good and evil.

Such a revocation and self-overcoming, however, even when presented as an historical development, does not in itself entirely eradicate the potential for resentment. Nietzsche describes morality as the "verhängnissvollsten Irrthum" of all time - it is a miscalculation with calamitous repercussions, engendering a deep resentment that at times is palpable in Nietzsche's writings. But Nietzsche does not present his Zarathustra as the simple antagonist of Zoroaster who corrects his precursor's mistake, nor as simply a literary extension of the historical prophet in a fictional drama of abnegation and contrition. He presents his Zarathustra as the historical Zoroaster, fusing the two in a relationship of historical identity that he transforms into one of logical necessity. Nietzsche overcomes the potential resentment against Zoroaster and his moral world order by acknowledging him and his cataclysmic error as necessary antecedents to Zarathustra.

The attenuated distinction between history and invention evident in Zarathustra's metaleptic portrayal arguably invites Nietzsche to rewrite history, but he does not do so directly. For to fundamentally alter the nature of that which must be overcome to suit him who has overcome it eliminates the event of overcoming. Nietzsche's account of the relation between the historical Zoroaster and his own Zarathustra rather colors history with the shades of the present, looking back to that which has been overcome and discerning within it the seed of that overcoming. When Nietzsche writes, "Zarathustra schuf diesen verhängnissvollsten Irrthum, die Moral: folglich muss er auch der erste sein, der ihn erkennt," (EH, Warum ich ein Schicksal bin 3) this folglich functions as the retroactive imposition of Nietzsche's characterization of Zarathustra upon the historical figure of Zoroaster. This is not so much an error in reasoning as an expression of affirmation. The blending of history and fiction enables Nietzsche to assert his preposterous logic, represented by the inverse application of the adverb folglich. Zarathustra emerges from Zoroaster not as the logical development of history as we would conventionally conceive of it, but as a demonstration of the will's power over the past. Not by actually changing the past, but by altering our interpretation of the past through such a preposterous characterization does one make out of the "Es war" a "So wollte ich es!" Zarathustra thus does not simply overcome Zoroaster; he redeems him by alleviating the demand for his redemption. Zarathustra becomes Zoroaster's destiny. Because Zarathustra and Zoroaster are one and the same, not separated by the distinction separating history from fiction, the one must be a natural extension of the other, hence the folglich, which can in fact only ever be asserted retroactively. 
The fictional prophet redeems the historical one, and in doing so becomes an instance of affirmation - the affirmation of even that which must be overcome, namely the moral world order. By recognizing in Zarathustra the affirmation of Zoroaster, we can account for the preposterous, i. e., retroactive, logic that Nietzsche employs in explaining his choice of figures. Identifying the prophet of good and evil behind the immoralist does not only complicate the figure of Zarathustra - it makes him stronger. It makes him stronger by demonstrating Zarathustra's capacity to overcome himself. It makes him stronger by demonstrating the author's capacity to affirm even that which must be overcome. It makes him stronger by demonstrating the will's power over its most overwhelming adversary: the past.

But, of course, one might counter that Nietzsche's explanation of the name Zarathustra in Ecce homo is too far removed from the composition of Also sprach Zarathustra to provide any genuine insight into the matter. Time had passed and Nietzsche's agenda had undergone revision. Indeed, the temporal distance between the two texts lies at the root of Janz' dissatisfaction with Nietzsche's account. But then, such a criticism would appear to miss the point, for Nietzsche transfigures his own past even as he transfigures that of Zarathustra. Zarathustra provides a performance of affirmation, consequently - folglich - he became the centerpiece of Also sprach Zarathustra - whether or not this notion actually predates the composition of the book. 